\title{
Sustainable agriculture education and civic engagement: The significance of community-university partnerships in the new agricultural paradigm
}

Kim L. Niewolny, ${ }^{a} *$ Virginia Tech, Department of Agricultural and Extension Education

Julie M. Grossman, ${ }^{\mathrm{b}}$ Department of Soil Science, North Carolina State University

Carmen J. Byker, ${ }^{\mathrm{c}}$ Montana State University, Department of Health \& Human Development

Jennifer L. Helms, ${ }^{\text {d }}$ Virginia Tech, Department of Agricultural and Extension Education

Susan F. Clark, ${ }^{e}$ Virginia Tech, Department of Human Nutrition, Foods and Exercise

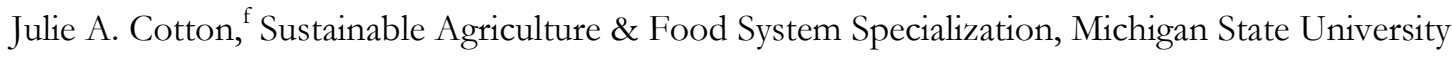

Krista L. Jacobsen, ${ }^{g}$ Department of Horticulture, University of Kentucky

Submitted 5 December 2011 / Revised 20 February and 18 March 2012 / Accepted 29 March 2012 / Published online 23 May 2012

Citation: Niewolny, K. L., Grossman, J. M., Byker, C. J., Helms, J. L., Clark, S. F., Cotton, J. A., \& Jocobsen, K. L. (2012).

Sustainable agriculture education and civic engagement: The significance of community-university partnerships in the

new agricultural paradigm. Journal of Agriculture, Food Systems, and Community Development, 2(3), 27-42.

http://dx.doi.org/10.5304/jafscd.2012.023.005

Copyright (C) 2012 by New Leaf Associates, Inc.

a, * Corresponding author: 282 Litton Reaves Hall, Department of Agricultural and Extension Education, Virginia Tech, Blacksburg, VA 24061 USA; +1-540-231-5784; niewolny@vt.edu

b 4234 Williams Hall, Department of Soil Science, North Carolina State University, Raleigh, NC 27695-7619 USA; +1-919-513-1041; julie grossman@ncsu.edu

c 222 Romney Gym, Department of Health \& Human Development, Montana State University, Bozeman, MT 59717 USA; +1-406-994-1952; carmen.byker@montana.edu

d 2270 Litton Reaves Hall, Department of Agricultural and Extension Education, Virginia Tech, Blacksburg, VA 24061 USA; +1-540-231-6836; jenniferhelms@vt.edu

e 202 Wallace Annex, Virginia Tech, Blacksburg, VA 24061 USA; +1-540-231-8768; sfclark@,vt.edu

${ }^{\mathrm{f}}$ A274 Plant \& Soil Science Building, Sustainable Agriculture \& Food System Specialization, Michigan State University, East Lansing, MI 48824 USA; +1-517-355-0271; cottonj@msu.edu

g N-310C Agricultural Sciences North, University of Kentucky, Lexington, KY 40546 USA; +1-859-257-3921; krista.jacobsen@,uky.edu

\begin{abstract}
Universities and colleges across the United States are making innovative strides in higher education programming to catalyze a more sustainable era of agriculture. This is clearly exemplified through the formation of community-university partnerships as critical illustrations of civic engagement (CE) for sustainable agriculture (SA) education. This paper explores the praxis of $\mathrm{CE}$ for $\mathrm{SA}$ education by focusing on the ways in which five land-grant universities (LGUs) with undergraduate programs in SA have developed and put into practice community-university partnerships. Drawing upon these programs and supportive literature, this article specifically attempts to describe the role and significance of $\mathrm{CE}$ for SA education, emerging community-university partnership models and their implications for prompting food and agriculture sustainability, and student learning and program assessment outcomes. We also reveal the many challenges and opportunities encountered by stakeholders involved in the creation and continu-
\end{abstract}


ation of these programs and their subsequent coursework. Conclusions offer "real world" recommendations for other faculty, staff, student, and community stakeholders to implement and generate action-oriented scholarship for and with communities as a viable thread of SA education.

\section{Keywords}

civic engagement, community-university partnerships, land-grant universities, sustainable agriculture education

\section{Introduction}

According to the National Academies of Science (National Research Council of the National Academies [NRC]; Division on Earth and Life Studies; Board on Agriculture and Natural Resources Board on Life Sciences, 2009), institutions of higher education should provide more agricultural education opportunities that take students "beyond the institution" (p. 6) so that our students may have direct access to civically engaged and real world learning experiences. These opportunities may include agriculture-orientated internships, off-campus service-learning opportunities, cooperative learning experiences with the agriculture industry, student-led seminars, and selfdirected practicums. The emergence of sustainable agriculture (SA) education ${ }^{1}$ is distinctively contemporaneous within this discourse through the resurgence of community-university partnerships. As our agriculture and food system is confronting environmental, economic, and social constraints, land-grant university (LGU) partnerships with communities are specifically mobilizing faculty, students, and community members toward a more sustainable era of agriculture by sharing resources and knowledge (Molnar, Ritz, Heller, \& Solecki, 2010).

While civic engagement (CE) varies across university landscapes, we focus our attention on

\footnotetext{
${ }^{1}$ Following the Sustainable Agriculture Education Association (SAEA), we define sustainable agriculture as "food and agricultural systems that are environmentally sound, economically viable, socially responsible, non-exploitative, humane, and that serve as a foundation for future generations" (SAEA, n.d., "Promoting the teaching and learning").
}

CE opportunities through the LGU lens with special emphasis on undergraduate education. The focus on applied sciences makes LGUs a natural fit for integrating $\mathrm{CE}$ with $\mathrm{SA}$ education programs. ${ }^{2}$ LGUs have a long history of outreach and education in which faculty, staff, and students work with community stakeholders to enhance agriculture knowledge and practice. Central to mutually beneficial engagement for communities and universities is "respecting roles, perspectives, needs, and sources of knowledge. It also means sharing information, knowledge, and wisdom, collaboratively defining problems, and jointly finding meaningful solutions to those problems" (Peters, Jordan, Adamek, \& Alter, 2005, p. 462). Including key examples of CE during LGU strategic plans can prioritize the needs of the community in education, research, and outreach agendas, resulting in the actualization of applied research with local knowledge and experience (NRC, 2009).

As we explore the emergence and significance of community-university partnerships in SA education through the lens of CE, we attempt to clarify some pertinent questions. First, what do we mean by $\mathrm{CE}$ for SA education? How are communityuniversity partnerships an illustration of $\mathrm{CE}$ for $\mathrm{SA}$ education, in theory and in practice? How are SA major and minor programs at LGUs incorporating community-university partnerships into their curricula? Drawing upon Melaville, Berg, and Blank (2006), what community-based learning strategies (e.g., agro-environmental, place-based, and servicebased) underpin these opportunities? How do we assess learning in community-based settings? And finally, what are the challenges and opportunities for this kind of CE at LGUs? The following is an attempt to answer these questions.

\section{Sustainable Agriculture Education Association Preconference Workshop} In August 2011, participants from several LGUs with majors or minors explicitly focusing on

\footnotetext{
${ }^{2}$ We acknowledge that program names may differ (e.g., sustainable agriculture, agroecology, organic agriculture, and food systems). For clarity and simplicity, we use the term sustainable agriculture (SA) education to collectively refer to all of these systems-based programs.
} 
sustainable agriculture and food systems discussed the state of sustainable agriculture programs at the participating institutions. The preconference workshop took place prior to the $4^{\text {th }}$ National Sustainable Agriculture Education Association (SAEA) Conference in Lexington, Kentucky. This full-day forum was designed as a unique opportunity for participants to develop regional and national-level collaborations at peer institutions to enhance their programming in areas of key national needs. As part of this facilitated workshop, faculty and student participants shared successes and challenges of meaningful engagement opportunities with community partners in their programming and instructional efforts. Our SA program experiences were among those shared at this workshop (see the introductory paper, "Sustainable Agriculture Undergraduate Degree Programs: A LandGrant University Mission” by Jacobsen, Niewolny, Schroeder-Moreno, Van Horn, Harmon, Chen Fanslow, Williams, and Parr in this issue for further details). The facilitated workshop was organized as a series of large- and small-group discussions and breakout sessions. These sessions were a mix of facilitator-led discussions and world café discussion sessions. Large-group discussions were digitally recorded, transcribed, and reviewed for common themes pertaining to our SA education experiences. World café discussion sessions were hand recorded and reviewed for similar and divergent themes as they emerged from the discussion.

While many topics emerged through workshop dialogue, the mutually constitutive nature of $\mathrm{CE}$ in our SA programs emerged as one of several major themes repeatedly discussed throughout the day. Four subsequent themes further informed our SA education programming knowledge and experiences as they pertained to the role of CE: community-university partnerships as a key example of CE in SA education; empirical models of community-university partnerships in our programs; community-based learning strategies supporting our SA education programs; and the purpose or utility of these community-university partnerships. Within each of these themes, insightful situations of struggle and achievement with our students, departments, colleges, and community groups were at the heart of our accounts. In this paper, we systematically draw upon a range of programmatic and scholarly literature to further frame these themes, and the evolution of our five LGU programs (Michigan State University, Montana State University, North Carolina State University, University of Kentucky, and Virginia Tech) with special emphasis on service learning, farm study, and self-directed practicums as empirical models of community-university partnerships in SA curricula. We purposely choose to focus on these models of community-university partnerships embedded in our sustainability curricula given their prominence in our programs. To that end, we reveal our SA program structures, educational content, learning audiences, and formative assessment methods and outcomes that help inform how these models are put into practice.

It should be noted that although somewhat common in practice, very little has been written on the relationship between CE and SA programs in higher education. Even less is written about the actual ways in which institutions of higher education are providing specific $\mathrm{CE}$ opportunities through SA programs. The focus on the role of $\mathrm{CE}$ in SA programs at LGUs was also intentional. As stated in the Introduction article in this issue, LGUs are rapidly providing new space for SA program development - despite the many challenges experienced along the way. Our experiences with SA education are also embedded within the LGU system. The authors acknowledge, however, that other universities and colleges (e.g., liberal art colleges) contribute to the SA education discourse in many important ways. As far as the authors are aware, this manuscript is the first to provide a comprehensive framework for $\mathrm{CE}$ that is specific to SA programs across several LGUs. Our aim is therefore to present a succinct case for $\mathrm{CE}$ in $\mathrm{SA}$ programs at LGUs so that our experiences may provide footing for others, both in and outside the LGU system. At a minimum, we have provided a starting point for this emerging discussion. We begin by exploring the role of civic agriculture as a promising framework to understand the role of $\mathrm{CE}$ in SA education. 


\section{Civic Agriculture as a Framework for CE in SA Education}

Agriculture and food systems have experienced several transformations over the last century. Guided by a growing (post)industrialized discourse, technological changes such as mechanization, synthetic inputs, and biotechnology have revolutionized agriculture. Increased specialization and transnational economic arrangements from production to consumption have further transformed agrofood system practices. In response to this globalized trajectory, a new agricultural paradigm has emerged that focuses on the "embedding of local agricultural and food production in the community" (Lyson, 2004, p. 62). This concept of "civic agriculture," as coined by Lyson (2004), supports strategies and enterprises for the reconfiguration of food production, distribution, and consumption in North America. Representative initiatives such as community supported agriculture (CSA), farmers' markets, community gardens, and farm-to-institution arrangements are growing rapidly by way of public participation and local support. For Hinrichs (2007), this civic agriculture paradigm sets the stage for new forms of knowledge, networks, and standards of agricultural practice through the dual aims of civic revitalization and food system transformation. A civically engaged agriculture is built through the foundations of social embeddedness, reciprocity, and trust (Tolbert, Irwin, Lyson, \& Nucci, 2002). In other words, a civically engaged foundation of agriculture may contribute to creating a democratic environment for higher levels of social wellness, capacity building, and community engagement.

The concept of civic agriculture has been applied in various contexts as a development paradigm. According to Thomson, Maretzki, and Harmon (2007) and Wright (2006), civic agricultural principles are undoubtedly applicable to educational frameworks. ${ }^{3}$ We further propose that civic agriculture may provide the conceptual groundwork for developing SA education that aims

\footnotetext{
${ }^{3}$ Not all programs mentioned here refer to civic agriculture as a pedagogical framework for SA education. Instead, the authors draw upon civic agriculture as a suitable theoretical foundation for discussion and application.
}

to strengthen students' understanding of the connections among food, agriculture, and the community. Community-university learning opportunities, for example, allow students and community members to join together in democratically structured ways that help reveal complex issues of food system hegemony, social justice, and food security (Colasanti, Reau, \& Wright, 2009). These community-based learning experiences also provide group capacity-building and collaborative leadership development for enhanced understanding and action (Wright, 2006). Others draw upon such formats as community forums and study circles to create dialogue about and envision a more sustainable agriculture and food system (Poincelot, Francis, \& Bird, 2006).

What makes these approaches unique for universities and colleges of agriculture is their commitment to serving the needs of students and community stakeholders. According to Hassanein (2003), democratic participation and CE are the means and ends for pragmatic learning to catalyze agriculture and food system transformation. By exposing students to community-learning opportunities in SA programs, we are in fact teaching them how to (re)structure the food system by way of eliciting the values, knowledge, and experiences of those involved in the food system (Colasanti et al., 2009). In other words, we are asking students to become directly involved in this change by learning with and within the community. In this light, we are creating the space for continued problemsolving and public dialogue that may actually inform a more sustainable food system.

\section{Community-University Partnerships Guided by the Land-Grant Mission}

Engagement is an essential component to the twenty-first-century LGU mission. It is connecting students, faculty, and community together in a mutually beneficial learning process and providing "an opportunity for all - faculty, staff, students, and public — to learn together in seeking solutions to real problems" (Byrne, 2000, p. 17). For Peters, Jordan, Adamek, and Alter (2005), the role of LGU faculty is to engage with the community with democratic and civic responsibility to problemsolve from a plethora of perspectives; here 
community actors bring "distinct but complementary motivations, interests, and goals to the table, as well as somewhat different understandings of the public issues that are at stake" (p. 38).

While the LGU has a clear responsibility to contribute to the community, student engagement has not been a primary way that universities have acted or served in communities. More extractive relationships, such as traditional student internships or faculty-guided research, have provided student learning opportunities; however, these opportunities have not necessarily reciprocated benefits to the community. Instead, communityuniversity partnerships, as primary examples of civic engagement, should build relationships that benefit the public good, therein serving the LGU mission and increasing community capacity simultaneously (Kellogg Commission on the Future of State Universities and Land-Grant Colleges, 1999).

Despite their mission, universities and communities frequently develop an antagonistic relationship (also known as the town and gown divide) for reasons such as campus separation from town life (McGirr, Kull, \& Enns, 2003), or perception of the community as merely a "client" for research (Bruning, McGrew, \& Cooper, 2006, p. 126). The apparent town and gown divide prompted the Kellogg Commission on the Future of State Universities and Land-Grant Colleges (1999) to petition higher education institutions for better collaboration with the public in order to problemsolve local and global issues in an increasingly complex society. Civically engaged activities can help integrate university activities with the local community. Public scholarship, the act of uniting scholarship and/or the arts with constituencies to form a partnership that addresses practical, localized issues, is also an avenue to engage campus and community with the intent for civic progress (Peters et al., 2005). SA is an appropriate common ground for universities and communities to problem-solve given prevalent concerns about the current food system's environmental impacts (Foley et al., 2005) and inability to provide immediate or future food security (Godfray et al., 2010).

\section{Models of Community-University Partnerships in SA Undergraduate Curriculum}

Having characterized the attributes, scope, and scale of CE for SA education, we now focus on three specific community-university partnership models taking place at five LGUs that illustrate what this looks like in practice: service-learning, farm study, and self-directed practicums. Table 1 in the appendix summarizes these models from our programmatic perspectives. Drawing upon Melaville, Berg, and Blank (2006), we focus on the description of SA education, community-university learning strategies, and the utility of the models that the five LGU programs have applied within SA coursework. While we focus on these five LGUs, it is important to note that the community-university partnerships in SA education vary from university to university. LGUs across the country are also assessing learning in similar yet distinctly different ways with regards to their CE opportunities. Other colleges and universities are uniquely contributing to the formation and refinement of community-university partnerships in SA education. It is important to note, however, that time and space limitations only allows for specific attention to be given to these five LGU programs.

Service-Learning. Service-learning is perhaps the most common form of CE through SA education. Each of our LGU SA programs demonstrate some form of service-learning. Focus group themes largely emphasized the way in which community-university partnerships are the driving force behind these learning opportunities for most of our programs. Service-learning can be defined as a teaching and learning strategy that integrates meaningful community service with instruction and reflection to enrich the learning experience, teach civic responsibility, and strengthen communities (Butin, 2010; Connors \& Seifert, 2005). The three characteristics of service-learning have been specifically defined as "learning and academic rigor, reflective thinking, and civic responsibility" (Duncan \& Kopperud, 2008, p. 7).

At our universities, partnerships between students and community organizations have emerged with the dual goals of improving student learning through civic empowerment, structured 
reflection on course content, and actively meeting the needs of the local community (Ash, Clayton, \& Atkinson, 2005). At the same time, such projects have also been shown to increase awareness of issues of social justice and societal inequities (Einfeld \& Collins, 2008; Eyler \& Giles, 1999 Hughes, Welsh, Mayer, Bolay, \& Southard, 2009). Preparing students to participate in society, being civically and politically engaged, and being socially responsible are desired educational outcomes of both service-learning and volunteerism (Strand, Cutforth, Stoecker, Marullo, \& Donohue, 2003). However, when compared to volunteerism, we argue that service-learning delves in deeper, asking students to analyze and synthesize their experiences in a formal manner.

From workshop discussions, we learned that the SA programs at our five LGUs similarly recognize how student engagement with community can encompass various time frames, from simple immersion activities consisting of only a few hours of community contact time, to a fully integrated, semester-length course with multiple contact points and the establishment of deeper relationships with community members. Examples of service-learning integrated into SA education curriculum from our institutions include one-day field trips to a community garden (e.g., North Caroline State University), one-week spring break service experience in an international location (e.g., Virginia Tech), and a semester-long project assisting local farmers via on-farm service visits (e.g., Michigan State University). These examples are further characterized as service-learning through a range of purposeful, critical-reflection writing assignments (e.g., reflection assignments using ePortfolios at Virginia Tech) that allow students to move beyond simple volunteerism toward a more civically engaged practice with community partners. This reflection-based pedagogy is central to engendering authentic service-learning (Duncan \& Kopperud, 2008; Eyler \& Giles, 1999).

Farm Study. In recent years, multiday farm study and tour courses have been developed with the intention of engaging students with agricultural course content and presenting them with the multidimensional challenges of agricultural production. Workshop discussants specifically noted farm study opportunities both within and outside of their home institutions (e.g., Iowa State University, Washington State University, University of Minnesota, University of Nebraska, University of Kentucky, and Michigan State University). Such courses often last from one week to 10 days, and include precourse readings and interviews with farm families focusing on production, economic, and social challenges. Particular emphasis is placed on student evaluation of interview responses, data analysis in small teams, and presentation of synthesized results in both oral and written forms. Such tours have been found to increase both student motivation for learning and retention of agricultural course content (Wiedenhoeft, Simmons, Salvador, McAndrews, Francis, King, \& Hole, 2003). Community partners are not as influential on curricula development or the reflection process using this learning strategy.

As an example from our set of five LGUs, the University of Kentucky incorporates a week-long farm study tour into the capstone course (SAG 490) of its SA undergraduate major. Throughout the first weeks of the semester-long course, students work with the instructor to create learning objectives and identify the types of agricultural enterprises they would like exposure to before completing the program. Working collaboratively, SAG students, faculty, and staff assemble a travel itinerary and spend the week interviewing farmers and reflecting on their experiences collectively over meals and travel times. Students then incorporate knowledge gained from the study tour into a final project focused on either planning for their future farm or building capacity for local organizations working on community food issues. The projects are presented as written reports and class presentations.

In another example outside our group of LGUs, faculty representing diverse disciplines from multiple institutions lead a study tour in which students review available methods and develop and utilize their own protocols for analyzing farm sites that compose "the assemblage of agroecosystems within the four state region of southwestern Minnesota, northwestern Iowa, southeastern South Dakota, and northeastern Nebraska" (DeHaan, Porter, Francis, \& Wiedenhoeft, 2011, p. 1). In this 
community-learning course, student teams pursue experiential learning and then prepare a document summarizing their farm analysis. Students then present their work in both oral workshops and a written final report. A highlight of this course is the completion of what is called a Learner Document, which provides an opportunity to reflect on the process by which students are learning during the week. This allows for formalizing the process as both an experience and an opportunity for learning that takes place as a result of the experience (Francis et al., 2011).

Self-Directed Engagement Practicum. Our focus group sessions further illustrated that selfdirected practicums were also often used as a community-engagement learning strategy. What composed the practicums, however, differed across our five LGUs programs. In discussion, it was agreed that the primary objective of a self-directed engagement practicum is for students and community partners to create a "useable" end product. In our programs, students are encouraged to exercise their creativity and learned knowledge, and to use a broad skill set to address an SA or food system topic that would be otherwise be difficult to encapsulate in teacher-centered coursework. These students often bring awareness of local agricultural and food system issues or of a topic or discipline that is of interest to the community. Interdisciplinary courses and programs can pose complications for instructors, as student learners' needs and goals vary. However, well-crafted practicum experiences that provide strong support for selfdirected projects can provide appropriate learning opportunities for each student.

In student-led projects within our LGUs, faculty assist students by providing a process and tools for students to carry out their own research or action-based community project. After determining a general topic and community partner, the student or student groups use provided templates to define their interests, roles, responsibilities, and expected outcomes with their community partners. By negotiating their relationships and end products with their community partner, they learn the constraints of the particular setting and environment. Instructors receive a formal project proposal, adapted appropriately to each practicum. Instruc- tors then aid students in locating additional resources needed to complete their work or negotiate their relationship with the community partner as needed.

Examples from Michigan State University's capstone course in Sustainable Agriculture and Food Systems include a documentary about dairy farmers who transitioned from confined to grazing operations that is utilized by outreach and extension, and a prototype composting program linking local food retail and service businesses with a local urban farm. Virginia Tech's Civic Agriculture and Food System (CAFS) capstone projects are structured similarly; examples of coursework include a movable campus demonstration garden, a school garden education program, and a Photovoice anthology of a campus farm and garden. Through these and similar learning experiences, students are provided the opportunity to accomplish a tangible food system goal, gain professional and personal skills, and to give community partners assistance that is of real and immediate value.

\section{Student Learning Through SA Curricula}

Our LGU program experiences provide a unique opportunity to place agriculture students in communities where they can learn (1) personal, (2) academic, and (3) professional skills (Grossman, Patel, \& Drinkwater, 2010; Jordan, Andow, \& Mercer, 2005; Motavalli, Patton, \& Miles, 2007). First, in some cases, according to Grossman, Patel, and Drinkwater (2010), civically engaged learning experiences may help students learn to personally and professionally interact with populations different from themselves and become aware of socioeconomic issues faced by disadvantaged populations. Such experience may provide students an advantage when seeking employment following graduation, for example, with new kinds of agricultural organizations requiring interaction with ethnically, economically, and culturally different populations from themselves. Perhaps more importantly, these experiences may also provide the necessary foundation for critical thinking and reflection about governing power structures (e.g., race, gender, class ideologies in the food system)enabling opportunities for social action and change 
as part of a tradition of emancipatory education (Brookfield, 2005; Hart, 1990).

Second, we argue that CE can serve to develop critical academic skills such as problem-solving and leadership. SA CE is particularly well-suited to engender these aims by way of linking classroom and field-based activities that place students in direct contact with professional organizations and farming activities such as field management (Parr, Trexler, Khanna, \& Battisti, 2007). Although our SA programs have been successful in providing professional development opportunities, we admit that the learning experience can be complex. Students often negotiate their time and commitments with those of their community partner, which can be challenging for everyone involved. As students are exposed to the "messiness" of the real world through their activities, however, we suggest that they learn lessons related to persistence, resource identification, and flexibility as they work toward accomplishing community-identified goals, often as a team (e.g., the CAFS capstone project at Virginia Tech).

Third, students may also be empowered to take an active role as citizens in their community and become agents of social change. Part of developing a sense a community occurs when individuals feel that they are members of a group (McMillan \& Chavis, 1986). Through CE, a "sense of place" is developed (DeLind, 2002, p. 222). Furthermore, CE frames SA in a way that places democratic participation at the focus of placedbased agriculture initiatives (Lyson, 2004). By promoting a sense of place and democratic principles through $\mathrm{CE}$ in civic agriculture, we promote the development of citizens who are members contributing to a particular place. Critical scholars such as Dewey (1897) and Freire (1970) have identified education as a means for social progress. While applying knowledge, students gain an understanding of value systems and how to change and strengthen them (Byrne, 2000). For example, one study showed that undergraduates participating in $\mathrm{CE}$ wanted to promote diversity and influence social structures (Astin \& Sax, 1998). While our programs illustrate several student learning outcomes, these social action outcomes have not yet been recorded. We now focus on how student learning is currently assessed within our SA education programs.

\section{Assessing Student Learning and Programmatic Outcomes}

Through the development of our programs, it is clear that tools to evaluate student-learning outcomes from CE activities are not well documented. Although mixed-methods are used, qualitative experience is difficult to quantify (Bringle \& Hatcher, 2009). To that end, each of our programs uses some form of reflective writing or verbal processing as part of a student learning assessment. For example, reflective writings and presentations are regarded as highly effective tools for students to critically compare their value system to their experience in order to facilitate deep learning (Connors \& Seifer, 2005). Such writings often ask students to define specific things they have learned, at what point in the experience they learned it, and what they will do with the knowledge in other facets of their life (Ash et al., 2005), in written form, oral form, or both. Qualitative focus groups and interviews held before and after the communityengaged experience can also help inform instructors about preconceptions that a student may have prior to an activity, and how that activity changed these perceptions (i.e., Virginia Tech CAFS minor). If such qualitative assessments are transcribed for content evaluation (Strauss, 1987), quotes can be extracted from these conversations and lend strength to any quantitative data collected, along with the generation of prominent themes across the learner population. Pre- and post surveys using Likert scales are often used to collect such quantitative data, comparing student self-assessments of particular learning objectives to the degree they felt increases in knowledge in particular areas. Often a triangulation is recommended, with at least two or more of these methods used in combination to draw a clear picture of student learning resulting from often complex engaged experiences. 


\section{Table 2. Assessment Methods and Outcomes}

Assessment Methods of Student Learning

- Student and community members interviews

- Postcourse surveys and/or evaluations

- Fieldwork reflective journal analysis

- Student focus groups

- Class fieldwork activities that integrate community partner

- Written community action project proposal development

- Capstone community action project

- Self, peer, faculty, and community evaluative feedback

We have drawn upon a variety of these methods to conduct assessments, many of which are formative. Given the young age of these programs, summative evaluations are still months and years away. However, for the purpose of reporting our current state of programming, we have compiled basic measures of assessment and outputs across our five programs. Table 2 illustrates our compiled assessment methods and outputs. ${ }^{4}$

\section{Challenges and Opportunities at Land-Grant Institutions}

During the SAEA preconference workshop in August 2011, participants shared their successes and challenges to meaningful engagement of community partners in their programming and instructional efforts. CE was widely acknowledged by all programs present as beneficial and integral to student learning and programmatic missions. However, the dialogue revealed common challenges to initiating, maintaining, assessing, and sustaining these relationships in the long term.

CE efforts are resource-intensive and require investment on the part of the community partner and the academic institution. Workshop participants noted the time and effort needed to cultivate relationships with community partners, be it through dialogue, planning and participating in service activities, or reciprocating efforts when

\footnotetext{
${ }^{4}$ Assessment methods used were drawn from Grossman, Patel, \& Drinkwater, 2010; Grossman, Sherard, Prohn, Bradley, Goodell, \& Andrew, in press; Huba \& Freed, 2000; Walvoord, 2004.
}

Student Learning Outcomes

- Leadership development

- Critical thinking analysis, problem-solving, adaptive skills

- Teaching and articulation skills

- Interacting with diverse audiences

- Networking

- Effective multidimensional communication skills

- Community project implementation

- Personal and professional growth

- Increased metacognition and civic engagement community partners request academic expertise. Some workshop participants expressed that although their institutions may be morally supportive of the efforts, and even enjoy positive publicity and improved community relations due to SAoriented CE activities, formal institutional support for these efforts is lacking. In the experience of workshop participants, CE efforts are often minimally funded and lack formal reward in traditional faculty evaluation structures. Further, there is opportunity cost within this structure for time spent cultivating community relationships that could otherwise be spent on efforts that receive merit (e.g., manuscript and grant writing, research activities, etc.).

We learned that building more integrated, positive community relationships take time, creativity, and commitment from both the educational institution and community partner. Considering the constrained choices of the community partner, be it economic, political, biophysical, social, or from any other source, is essential in providing a service of value. Instructors are implicitly or explicitly asking our community partners for time, training, or accommodation, which has a real cost to them or their organization. This lack of understanding of the resources required of community partners to host activities and experiences can potentially overtax the relationship and saturate the partner with students and requests for involvement (e.g., volunteer events, interns, tours, etc.). While the benefits may exceed these costs, understanding how engagement affects the community partner is important in tending to this relationship. Most 
organizations have finite resources and care must be taken to design experiences that do not overburden the community partner. Aiming to have a mutually beneficial long-term relationship requires that the services students provide be worthwhile, and that the engagement remains appropriate to the changing needs of the community. Likewise, sharing these considerations with students prepares them by providing context for the experience; this can lead to more successful engagement efforts.

Similarly, we learned that community partners are not traditionally rewarded for their contributions as sources of knowledge and agents of change in communities, but rather as recipients of service. It is important to acknowledge community partners' time and expertise. Examples of such acknowledgement from our programs include honoraria for farm tours and speaking events, contribution of resources (e.g. farm supplies, money, expertise) to service-learning projects, or praising the community partner's work at public events or in media.

We also put forward that there are many opportunities to better equip students to work in communities more effectively. For example, some faculty in this case have designed precourse training to help prepare students for working with diverse audiences and offering basic skill-building in teaching and outreach realms (e.g., Smith \& Grossman, 2011). Such training often takes place in structured sessions prior to engagement with the community and provides a forum for learning about community partner organization and goals through guest lectures. In other instances, training manuals have served this purpose. A training manual outlines specific expectations about student conduct, community partner roles, and faculty responsibilities. A guide that details modes of communication, avenues for actualizing the project, and assessment tools can help relieve anxieties about properly managing a project, representing the university and community in a positive manner, and, ultimately, ensuring sustainability of a community-university partnership because of good relations.

In addition to a common lack of widespread institutional support and funding for $\mathrm{CE}$ activities, SAEA workshop participants noted that instruc- tors incorporating CE activities into their coursework have not typically received formal training in constructing activities and assessing student learning. More often instructors have been classically trained along traditional disciplinary lines such as soil science, agronomy or ecology; teaching SA curricula is often just a portion of their teaching activities. Community engagement efforts in their programs are motivated by an inherent valuation of community partners as sources of information and "real world" application. Thus, many of the workshop participants were learning to cultivate community partnerships through independent research on pedagogy and assessment, or informal networks and resource exchanges with peers.

\section{Conclusion and Recommendations}

By drawing upon programmatic and scholarly literature, and our lived experiences in developing civically engaged SA curricula, we have illustrated how a portion of higher education is moving toward a civically engaged future in relation to education for and about SA and food systems. LGUs have a responsibility to contribute to the community. Until recently student engagement in SA education was not a primary way that universities acted or served in communities. In response, we argue that the foundations of civic agriculture can be applied to SA programming to increase public dialogue, problem-solving capacities, and social action. We also argue that communityuniversity partnerships are primary examples of $\mathrm{CE}$ in SA education. To that end, we drew upon various bodies of literature to frame the way our LGUs have created and sustained three specific models of community-university partnerships: service-learning, farm study, and self-directed practicums. Table 1 in the appendix summarizes these models. Our institutions do not use these models in isolation; instead, we draw upon elements of each model across our programs to effectively inform our students' experiences. Here we described how farm study opportunities have been shown to promote critical thinking while connecting student-centered topics in SA. The selfdirected practicum example has been established as a place-based learning strategy where stakeholders work to discover capacities to mobilize assets for 
community improvement. Service-learning is shown to connect community service to academic studies with reflection activities integrated into the curricula. The utility of this model addresses community needs and confers significant benefits to community partners.

We also focused on student learning outcomes and assessment measures, including but not limited to leadership development, critical thinking analysis, problem-solving, cultural awareness, communication skills, personal and professional growth, and increased metacognition through real-world application of SA skills and knowledge. Finally, we shared the ways in which these SA programs have not only been successfully created, but discuss the pitfalls that have occurred along the way. Of critical importance here is the need for open dialogue with stakeholders about programmatic assumptions. For example, concerns over administrator support for engagement efforts are a driver for ongoing dialogue about programmatic sustainability.

In building upon these ideas, we conclude with the following recommendations. While not exhaustive, these suggestions serve as a model for establishing and sustaining CE in SA programs within higher education institutions.

\section{Recommendations for community practitioners:}

- Reach out to university faculty who might provide content-area expertise and resources to mutually problem-solve.

- Proactively communicate your needs and expectations to university partners.

- Be honest about volunteer capacity, time limitations, and resource constraints.

- Be prepared to both teach and learn content knowledge and skills.

\section{Recommendations for faculty:}

- Incorporate community-based learning strategies into coursework requirements such as service learning, case studies, farm tours, or self-directed practicums. Create an avenue for reflection in $\mathrm{CE}$ approaches.

- Communicate clear expectations for the roles of all involved: students, community partners, and faculty members.
- Develop a standard protocol for universitycommunity interactions, including a training manual for students and an acknowledgement structure for community partners.

- Help students learn about themselves and what they are learning by creating opportunities for personal reflection through journals or reflection-oriented assignments.

\section{Recommendations for students:}

- Understand that community partners are often juggling multiple projects and may rely on volunteers for a significant portion of their labor.

- Be open and flexible with scheduling and tasks whenever possible. Follow through when you make a commitment to an organization or farmer.

- Follow established protocol for CE activities and realize that you are a representative of the university.

- Actively link hands-on experiences with course concepts by making connections between field activities and related coursework and engaging in dialogue with peers, faculty, and community partners.

\section{Acknowledgements}

We would like to give generous thanks to our students, faculty colleagues, and community partners who contribute to the programs at the Michigan State University, Montana State University, North Carolina State University, University of Kentucky, and Virginia Tech. We are also grateful for our friends and supporters of the Sustainable Agriculture Education Association. 


\section{Appendix}

\section{Table 1. Categorization of CE for SA Education}

\begin{tabular}{|c|c|c|c|c|}
\hline $\begin{array}{l}\text { Models of } \\
\text { Community- } \\
\text { University } \\
\text { Partnerships for } \\
\text { SA Education }\end{array}$ & $\begin{array}{l}\text { Description of SA } \\
\text { Education }\end{array}$ & $\begin{array}{l}\text { Community-Based } \\
\text { Learning Strategies } \\
\text { Supporting SA Educationa }\end{array}$ & $\begin{array}{c}\text { Community-University } \\
\text { Utility }\end{array}$ & $\begin{array}{l}\text { Exemplar } \\
\text { University } \\
\text { Program }^{b}\end{array}$ \\
\hline Farm Study & $\begin{array}{l}\text { Experiential learning } \\
\text { activities on working farms } \\
\text { with focus on exploring SA } \\
\text { production practices (i.e., } \\
\text { hands-on learning in } \\
\text { student and university farm } \\
\text { settings). }\end{array}$ & $\begin{array}{l}\text { "Agro-environmental" } \\
\text { That is, learning that uses } \\
\text { agriculture and life science } \\
\text { settings to build upon } \\
\text { student interest and } \\
\text { experience }\end{array}$ & $\begin{array}{l}\text { Recognition and } \\
\text { application of SA } \\
\text { knowledge using } \\
\text { experiential, hands-on } \\
\text { methods. }\end{array}$ & $\begin{array}{l}\text { MSU } \\
\text { NCSU } \\
\text { UK }\end{array}$ \\
\hline $\begin{array}{l}\text { Self-Directed } \\
\text { Practicum }\end{array}$ & $\begin{array}{l}\text { Stakeholders work to } \\
\text { discover capacities to } \\
\text { mobilize assets for } \\
\text { community improvement } \\
\text { (e.g., internship on a farm; } \\
\text { co-directed asset-based } \\
\text { community food system } \\
\text { planning). }\end{array}$ & $\begin{array}{l}\text { "Place-based" } \\
\text { That is, student } \\
\text { engagement is directed } \\
\text { toward specific community } \\
\text { needs and interests; } \\
\text { community members serve } \\
\text { as resources and partners } \\
\text { in every aspect of teaching } \\
\text { and learning. }\end{array}$ & $\begin{array}{l}\text { Community partners can } \\
\text { both set the SA agenda } \\
\text { and evaluate work; they } \\
\text { serve as respected } \\
\text { partners and contributors, } \\
\text { and cogenerate SA } \\
\text { knowledge. }\end{array}$ & $\begin{array}{l}\text { MSU } \\
\text { MoSU } \\
\text { NCSU } \\
\text { UK } \\
\text { VT }\end{array}$ \\
\hline Service-Learning & $\begin{array}{l}\text { Connecting community } \\
\text { service to academic } \\
\text { studies with integrated } \\
\text { reflection activities (e.g., } \\
\text { spring break service } \\
\text { experience; semester-long } \\
\text { service projects assisting } \\
\text { farmers, community } \\
\text { gardens, food banks, and } \\
\text { community kitchens). }\end{array}$ & $\begin{array}{l}\text { "Service-based" } \\
\text { That is, service activity } \\
\text { meets actual needs of the } \\
\text { community partner } \\
\text { identified by students and } \\
\text { community partners. } \\
\text { Learning is integrated with } \\
\text { in-class work and student } \\
\text { reflection. }\end{array}$ & $\begin{array}{l}\text { Addresses community } \\
\text { needs and confers } \\
\text { significant benefits to } \\
\text { community partner setting; } \\
\text { students learn to critically } \\
\text { evaluate their experience } \\
\text { through reflection. }\end{array}$ & $\begin{array}{l}\text { MSU } \\
\text { MoSU } \\
\text { NCSU } \\
\text { UK } \\
\text { VT }\end{array}$ \\
\hline
\end{tabular}

a Descriptions adapted from Melaville, Berg, \& Blank (2006)

b University program abbreviations: Michigan State University (MSU), Sustainable Agriculture and Food Systems (B.S. \& B.A. specialization); Montana State University (MoSU), Sustainable Food Systems Program (B.S major); North Carolina State University (NCSU), Plant \& Soil Sciences major with an Agroecology B.S. concentration; University of Kentucky (UK), Sustainable Agriculture (SAG) Program (B.S. major and minor); Virginia Tech (VT), Civic Agriculture and Food Systems (CAFS) (B.S. minor). 


\section{References}

Ash, S. L., Clayton, P., \& Atkinson, M. (2005). Integrating reflection and assessment to capture and improve student learning. Michigan Journal of Community Service Learning, 11(2), 45-59.

Astin, A. W., \& Sax, L. J. (1998). How undergraduates are affected by service participation. The Journal of College Student Development, 39(3), 251-263.

Bringle, R., \& Hatcher, J. (2009). Innovative practices in service-learning and curricular engagement. New Directions for Higher Education, 147(Fall), 37-46. http://dx.doi.org/10.1002/he.356

Brookfield, S. (2005). The power of critical theory: Liberating adult learning and teaching. San Francisco, CA: JosseyBass.

Bruning, S. D., McGrew, S., \& Cooper, M. (2006). Town-gown relationships: Exploring universitycommunity engagement from the perspective of community members. Public Relations Review, 32(2), 125-130. http://dx.doi.org/10.1016/i.pubrev.2006.02.005

Butin, D. W. (2010). Service-learning in theory and practice. New York: Palgrave Macmillan. http://dx.doi.org/10.1057/9780230106154

Byrne, J. V. (2000). Engagement: A defining characteristic of the university of tomorrow. Journal of Higher Education Outreach and Engagement, 6(1), 13-21.

Colasanti, K., Wright, W., \& Reau, B. (2009). Extension, the land-grant mission, and civic agriculture: Cultivating change. Journal of Extension, 47(4). Retrieved from http://www.joe.org/joe/2009august/a1.php

Connors, K., \& Seifer, S. D. (2005). Reflection in higher education service-learning. Retrieved from Learn and Serve America's National Service-Learning Clearinghouse website: http://www.servicelearning.org/instant_info/fact_ sheets/he facts/he reflection

DeHaan, R., Porter, P., Francis, C., \& Wiedenhoeft, M. (2011). Agroecosystems analysis field course (Unpublished course syllabus). Dordt College, University of Minnesota, University of Nebraska, and Iowa State University.

DeLind, L. B. (2002). Place, work, and civic agriculture: Common fields for cultivation. Agriculture and Human Values, 19(3), 217-224. http://dx.doi.org/10.1023/A:1019994728252
Dewey, J. (1897). My pedagogic creed. The School Journal, 54(3), 77-80.

Duncan, D., \& Kopperud, J. (2008). Service-learning companion. Boston, Massachusetts: Houghton Mifflin Company.

Einfeld, A., \& Collins, D. (2008). The relationships between service-learning, social justice, multicultural competence, and civic engagement. Journal of College Student Development, 49(2), 95-109. http://dx.doi.org/10.1353/csd.2008.0017

Eyler, J., \& Giles, D. (1999). Where's the learning in servicelearning? San Francisco, California: Jossey-Bass.

Foley, J. A., DeFries, R., Asner, G. P., Barford, C., Bonan, G., Carpenter, S. R.,...Snyder, P. K. (2005). Global consequences of land use. Science, 309(5734), 570-574. http://dx.doi.org/10.1126/science.1111772

Francis, C. A., Jordan, N., Porter, P., Breland, T. A., Lieblein, G., Salomonsson, L., Langer, V. (2011). Innovative education in agroecology: Experiential learning for a sustainable agriculture. Critical Reviews in Plant Sciences, 30(1), 226-237. http://dx.doi.org/10.1080/07352689.2011.554497

Friere, P. (1970). Pedagogy of the oppressed. New York: Continuum.

Godfray, H. C. J., Beddington, J. R., Crute, I. R., Haddad, L., Lawrence, D., Muir, J., ...Toulmin, C. (2010). Food security: The challenge of feeding 9 billion people. Science, 327(5967), 812-818. http://dx.doi.org/10.1126/science.1185383

Grossman, J. M., Patel, M., \& Drinkwater, L. E. (2010). Enhancing undergraduate agro-ecological laboratory employment through experiential learning. Journal of Natural Resources \& Life Sciences Education, 39(1), 31-39. http://dx.doi.org/10.4195/jnrlse.2009.0017n

Grossman, J., Sherard, M., Prohn, S.M., Bradley, L., Goodell, S., Andrew, K. (In press). An exploratory analysis of student-community interactions in urban agriculture. Journal of Higher Education Outreach and Engagement.

Hart, M.U. (1990). Liberation through consciousness raising. In J. Mezirow and Associates (Eds.), Fostering critical reflection in adulthood: A guide to transformative and emancipatory learning (pp. 47-73). San Francisco, CA: Jossey Bass. 
Hassanein, N. (2003). Practicing food democracy: A pragmatic politics of transformation. Journal of Rural Studies, 19, 77-86.

Hinrichs, C. C. (2007). Introduction: Practice and place in remaking the food system. In C. C. Hinrichs \& T. A. Lyson (Eds.), Remaking the North American food system: Strategies for sustainability (pp. 1-15). Lincoln, Nebraska: University of Nebraska Press.

Huba, M. E., \& Freed, J. E. (2000). Learner-centered assessment on college campuses: Shifting the focus from teaching to learning. Needham Heights: Allyn \& Bacon.

Hughes C., Welsh, M., Mayer, A., Bolay, J., \& Southard, K. (2009). An innovative university-based mentoring program: Affecting college students' attitudes and engagement. Michigan Journal of Community Service Learning, 16(1), 69-78.

Tolbert, C. M., Irwin, M. D., Lyson, T. A., \& Nucci, A. R. (2002). Civic community in small-town America: How civic welfare is influenced by local capitalism and civic engagement. Rural Sociology. 67(1), 90-113. http://dx.doi.org/10.1111/i.1549-0831.2002. tb00095.x

Jordan, N. R., Andow, D. A., \& Mercer, K. L. (2005). New concepts in agroecology: A service-learning course. Journal of Natural Resources and Life Sciences Education, 34, 83-89.

Kellogg Commission on the Future of State and LandGrant Colleges. (1999). Returning to our roots: The engaged institution. Washington, D.C.: National Association of State Universities and Land-Grant Colleges.

Lyson, T. (2004). Civic agriculture: Reconnecting farm, food, and community. Medford, Massachusetts: Tufts University Press.

McGirr, D., Kull, R., \& Enns, K. S. (2003). Town and gown. Economic Development Journal, 2, 16-23.

McMillan, D. W., \& Chavis, D. M. (1986). Sense of community: A definition and theory. Journal of Community Psychology, 14(1), 6-23. http://dx.doi.org/10.1002/1520-6629(198601) 14:1\%3C6::AID-JCOP2290140103\%3E3.0.CO;2-I

Melaville, A., Berg, A. C., \& Blank, M. J. (2006). Community-based learning: Engaging students for success and citizenship. Coalition for Community Schools. Retrieved from http://www.communityschools. org/assets/1/AssetManager/CBLFinal.pdf

Molnar, C., Ritz, T., Heller, B., \& Solecki, W. (2010). Using higher education-community partnerships to promote urban sustainability. Environment: Science and Policy for Sustainable Development, 53(1), 18-28. http://dx.doi.org/10.1080/00139157.2011.539944

Motavalli, P., Patton, M. D., \& Miles, R. J. (2007). Use of web-based student extension publications to improve undergraduate student writing skills. Journal of Natural Resources and Life Sciences Education, 36(1), 95-102.

National Research Council of the National Academies [NRC]; Division on Earth and Life Studies; Board on Agriculture and Natural Resources Board on Life Sciences. (2009). Transforming agricultural education for a changing world. Washington, D.C.: The National Academies Press.

Parr, D., Trexler, C., Khanna, N., \& Battisti, B. (2007). Designing sustainable agriculture education: Academics' suggestions for an undergraduate curriculum at a land-grant university. Agriculture and Human Values, 24(4), 523-33.

Peters, S. J., Jordan, N. R., Adamek, M., \& Alter, T. R. (Eds.). (2005). Engaging campus and community: The practice of public scholarship in the state and land-grant university system. Dayton, Ohio: The Kettering Foundation Press.

Poincelot, R. P., Francis, C. A., \& Bird, G. W. (2006). Overview of the educational social contract: Building a foundation for sustainable agriculture. In C. Francis, R. Poincelt, \& G. Bird (Eds.), Developing and extending sustainable agriculture: A new social contract (pp. 1-23). Binghamton, New York: Haworth Press. Smith, S., \& Grossman, J. (2011, Oct 15-19). Preparing students for a diverse future: Designing and evaluating a cultural competency training program for community engagement in agriculture. Published abstract, Soil Science Society of America International Meetings. San Antonio, Texas.

Strand, K. J., Cutforth, N., Stoecker, R., Marullo, S., \& Donohue, P. (2003). Community-based research and bigher education: Principles and practices. San Francisco : Jossey-Bass.

Strauss, A. L. (1987). Qualitative analysis for social scientists. Cambridge, UK: Cambridge University Press. http://dx.doi.org/10.1017/CBO9780511557842

Sustainable Agriculture Education Association [SAEA]. (n.d.). Promoting the teaching and learning of sustainable agriculture. Retrieved from http://www.sustainableaged.org/About/tabid/ 56/Default.aspx 
Thomson, J. S., Maretzki, A. N., \& Harmon, A. H. (2007). Community-initiated dialogue: Strengthening the community through the local food system. In C. C. Hinrichs \& T. A. Lyson (Eds.), Remaking the North American food system: Strategies for sustainability (pp. 183-200). Lincoln and London: University of Nebraska Press.

Walvoord, B. E. (2004). Assessment clear and simple: A practical guide for institutions, departments, and general education (Second edition). San Francisco: JosseyBass.
Wiedenhoeft, M., Simmons, S., Salvador, R., McAndrews, G., Francis, C., King, J., \& Hole, D. (2003). Agroecosystems analysis from the grass roots: A multidimensional experiential learning course. Journal of Natural Resources and Life Science Education, 32, 73-79.

Wright, W. D. (2006). Civic engagement through civic agriculture: Using food to link classroom and community. Teaching Sociology, 34(3), 224-235. http://dx.doi.org/10.1177/0092055X0603400302 